Check for updates

Cite this: RSC Adv., 2019, 9, 4781

\title{
Sulfur, mercury, and boron adducts of sydnone imine derived anionic $\mathrm{N}$-heterocyclic carbenes $\uparrow$
}

\author{
Tyll Freese, ${ }^{a}$ Jan C. Namyslo, ${ }^{a}$ Martin Nieger ${ }^{\mathrm{b}}$ and Andreas Schmidt (D) *a
}

The sydnone imines (5-benzoylimino)-3-(2-methoxyphenyl)-sydnone imine and molsidomine were deprotonated at C4 to give sydnone imine anions which can be represented as anionic $\mathrm{N}$-heterocyclic carbenes, respectively. Trapping reactions with sulfur gave unstable sydnone imine sulfides which were stabilized by the formation of methyl thioethers, methyl sulfoxides, gold complexes [( $\left(\mathrm{PP}_{3}\right) \mathrm{Au}-\mathrm{S}$-sydnone imine] and a bis(ligand) mercury(॥) complex. The latter possesses a tetrahedral coordination of the mercury central atom to the sulfur atoms with the N6 nitrogen atoms coordinating as neutral ligands. Water converted the molsidomine anion into ethyl(2morpholino-2-thioxoacetyl)carbamate. Mercury(I)chloride and triphenylborane were employed to trap the sydnone imine carbenes as mercury complexes as well as $\mathrm{BPh}_{3}$ adducts.

Received 12th January 2019 Accepted 31st January 2019

DOI: $10.1039 / c 9 r a 00294 d$

rsc.li/rsc-advances react similarly to give the corresponding NHCs in situ, respectively. In general, the extrusion of heterocumulenes from pseudo-cross-conjugated mesomeric betaines is a valuable tool to generate NHCs. By contrast, cross-conjugated mesomeric betaines (CCMB) such as pyrazolium-4-carboxylates 3 require harsh reaction conditions for the formation of remote $\mathrm{N}$ heterocyclic carbenes 4 so that this approach is not useful from a synthetic point of view. ${ }^{10}$ Some mesomeric betaines undergo reactions via their formal tautomers which are $\mathrm{N}$ heterocyclic carbenes. The CMB 5 and the CCMB 7 are examples. Thus, nitron 5 reacts with sulfur to give a urea derivative as formal trapping product of the carbene $6 .^{11}$ According to a computational study on relative stabilities of mesoionic and $\mathrm{N}$-heterocyclic carbene tautomers in dependence on substituent effects, nitron 5 is by $2.3 \mathrm{kcal} \mathrm{mol}^{-1}$ more stable than its carbene $6 .{ }^{12}$ Similarly, betaine 7 tautomerizes to give carbene $8 .{ }^{13}$ Deprotonation of mesomeric betaines such as 9 results in the formation of anionic N-heterocyclic carbenes 10 (Scheme 1). ${ }^{14}$
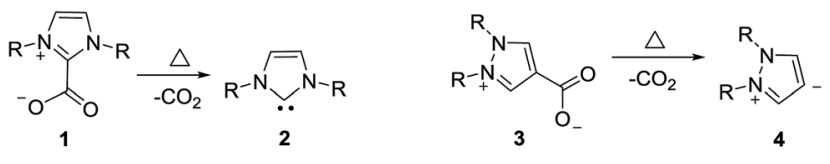
the generation of NHCs 2 , because they decarboxylate thermally under relatively mild conditions. ${ }^{6}$ Pyrazolium-3-carboxylates, ${ }^{7}$ indazolium-3-carboxylates, ${ }^{8}$ and pyridinium-2-carboxylates $^{9}$

${ }^{a}$ Clausthal University of Technology, Institute of Organic Chemistry, Leibnizstrasse 6, Clausthal-Zellerfeld, D-38678, Germany.E-mail: schmidt@ioc.tu-clausthal.de ${ }^{b}$ Department of Chemistry, University of Helsinki, P. O. Box 55, FIN-00014, Finland $\dagger$ Electronic supplementary information (ESI) available: Spectra, details of the X-ray analyses. CCDC 1889199 (27a), 1889200 (28a), 1889201 (29), 1889202 (30a) and 1889203 (31a) contain the supplementary crystallographic data for this paper. For ESI and crystallographic data in CIF or other electronic format see DOI: $10.1039 / \mathrm{c} 9 \mathrm{ra00294d}$

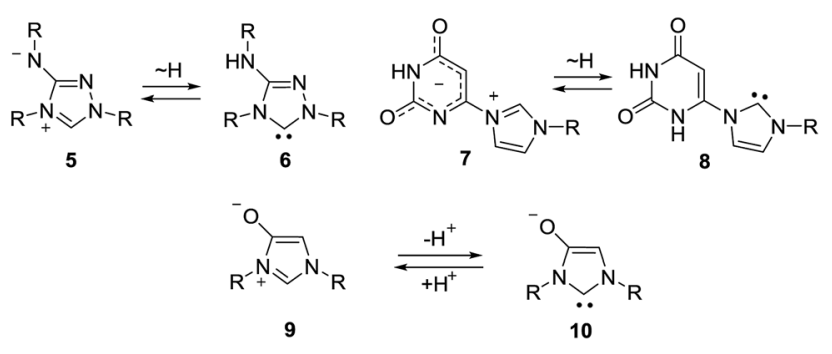

Scheme 1 Examples of mesomeric betaine - N-heterocyclic carbene transformations. 
Sydnones $(Z=O)$ and their derivatives such as sydnone imines $(\mathrm{Z}=\mathrm{NR})$ and sydnone methides $\left(\mathrm{Z}=\mathrm{CR}_{2}\right)$ belong to the class of conjugated mesomeric betaines (CMB). Although the canonical structure $\mathbf{I}$ is the most common, the resonance structures II and III indicate that the exocyclic $\mathrm{C}-\mathrm{X}$ bond corresponds to a carbonyl group for $\mathrm{X}=\mathrm{O}$ which is in well agreement to results of X-ray analyses as well as vibrational spectroscopy. ${ }^{15}$ Sydnones and their derivatives possess the dipole type $\mathbf{I V} / \mathbf{V}$ which is characteristic of the class of conjugated mesomeric betaines (CMB) (Scheme 2). ${ }^{3}$

The anions of sydnones and sydnone imines can be represented as anionic normal NHCs and abnormal NHCs. In the resonance forms, the delocalization of the negative charge of sydnone and sydnone imine anions include the site of deprotonation, i.e. $\mathbf{C} 4(\mathbf{V I})$, which is a starred (active) position according to a connectivity analysis (VII). ${ }^{2}$ Thus, anions of sydnone derivatives combine the features of N-heterocyclic carbenes due to their $\sigma$ lone pair and of conjugated mesomeric betaines due to their $\pi$ architecture. Consequently, the highest occupied molecular orbitals (HOMO) are $\pi$-orbitals which display large atomic orbital coefficients on C4 (Scheme 3).

The sydnone imine anion $\mathbf{1 2}(\mathrm{Z}=\mathrm{NR})$, usually stabilized by $\mathrm{Li}^{+}$, can be deuterated (13) and trapped by selenium, followed by methylation to give $\mathbf{1 4} \cdot{ }^{\mathbf{1 6}}$ It forms palladium as well as gold complexes such as $\mathbf{1 5}$ and $\mathbf{1 6} .^{16}$ Iminium salts of formimidate are able to formylate the sydnone imine anions to yield $17,{ }^{17}$ and the treatment with aldehydes give alcohols such as $18 .{ }^{18}$ Trapping with isocyanates give amides $(\mathbf{1 9}),{ }^{19}$ and treatment with chlorodiphenylphosphane give phosphorus adducts like $20{ }^{20}$ Some cross-coupling reactions, catalyzed by $\mathrm{Pd}\left(\mathrm{PPh}_{3}\right)_{4}$ and copper salts, to yield 21 and 22 were also described. ${ }^{18}$ In addition to that, rearrangements of $\mathbf{1 2}$ have been reported. ${ }^{19}$

In continuation of our studies directed toward the chemistry of mesomeric betaines and their conversions into $\mathrm{N}$ heterocyclic carbenes, we describe here trapping reactions of sydnone imine anions with sulfur, boron, and mercury.

\section{Results and discussion}

The sydnone imine anions 12a,b, generated on treatment of the sydnone imines 23a and 23b ("molsidomine") with lithium (trimethylsilyl)amide at rt, can be trapped by sulfur to give the corresponding sulfides $\mathbf{2 4 a}$, b which could not be isolated (Scheme 5). Thiols of sydnone imines are very rare. ${ }^{21}$ Methylation by modified literature procedures yielded the stable $^{21,22}$ sydnone imine thioethers 25a,b in acceptable yields. We were able to oxidize the thioethers $\mathbf{2 5 a}$,b with $m$-chloroperoxybenzoic acid to

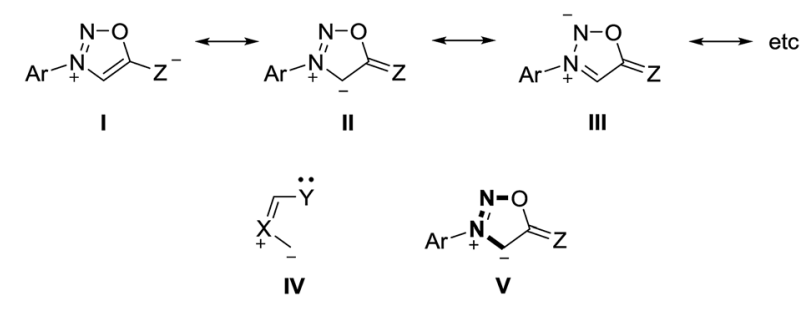

Scheme 2 Features of sydnone derivatives.

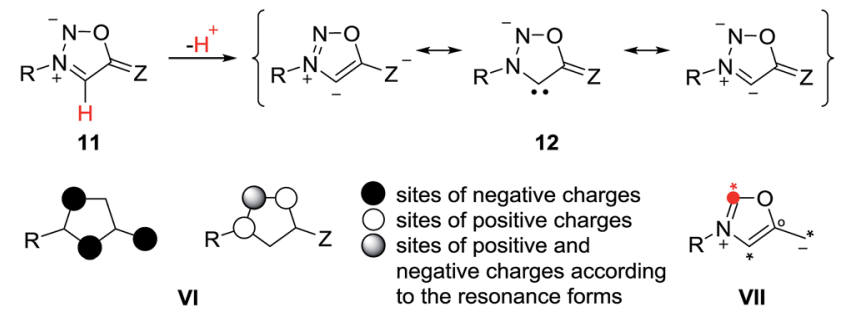

Scheme 3 Characteristics of sydnone anions and of their derivatives.

give the sulfoxides 26a,b. Stabilization of the sulfides as gold complexes was accomplished on treatment of freshly prepared samples of the sulfides with chloro(triphenylphosphine)gold(I) which resulted in the formation of the complexes $27 \mathbf{a}, \mathbf{b}$. These complexes supplement the complexes $\mathbf{1 6}$ (Scheme 4) in which the gold is directly attached to $\mathrm{C} 4$ of the sydnone imines and which we described earlier. ${ }^{16}$ Although the complexes 27a,b are stable enough to survive purification by column chromatography, gold complexes with the transition metal directly bound to the $\mathrm{C} 4$ carbene carbon atom are far more stable. The sulfides were also stabilized as mercury complexes $\mathbf{2 8 a} \mathbf{b} \mathbf{b}$ which were formed on exposure of the sulfides with mercury(II)chloride. Metal-stabilized sydnone sulfides are rare. To the best of our knowledge, only one tin complex has been described so far. ${ }^{23}$

Single crystals of the gold complex 27 a were obtained by slow crystallization at $-20^{\circ} \mathrm{C}$ in a $\mathrm{CHCl}_{3}$-EtOAc mixture (Fig. 1). It is noteworthy to point out the angle P1-Au1-S1 is $168.824(19)^{\circ}$ which is slightly bent towards the N6 nitrogen atom and not linear.

Single crystals of the mercury complex 28a were obtained by slow evaporation of a saturated solution in chloroform and diethyl ether. The complex crystallized in an orthorhombic space group. Crystal data show a bis(ligand) mercury(II) complex with tetrahedral coordination of the mercury central atom with the N6 nitrogen atoms coordinating as neutral ligands (Fig. 2). Furthermore, the N6 coordination has a major influence on the C4-S1-metal angle. While the C4-S1-Au1 angle of complex 27a adopts a value of $101.65(7)^{\circ}$, the corresponding angle of the bis(ligand) mercury(II) complex 28a has a value of $94.02(7)^{\circ}$ (C34-S31-Au1 95.39(7) ${ }^{\circ}$.

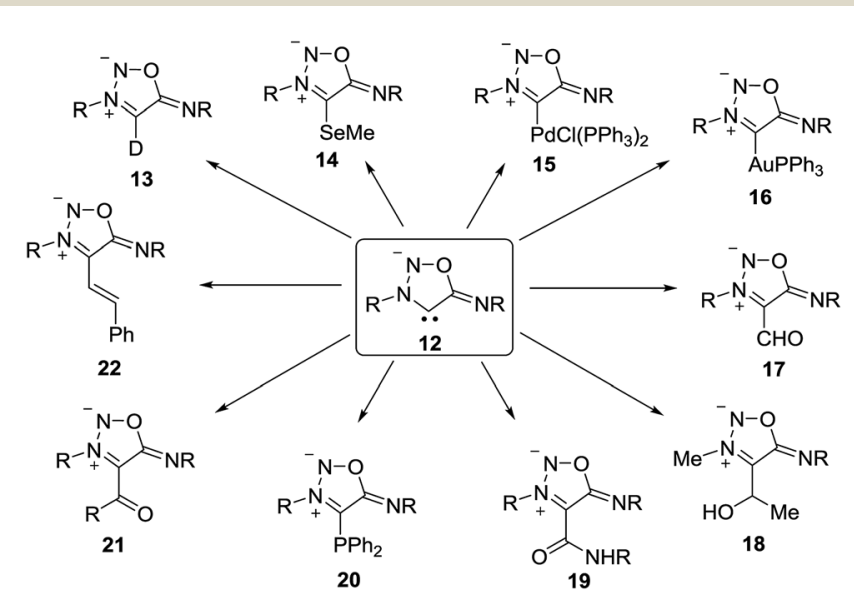

Scheme 4 Reactions of sydnone imine anions. 

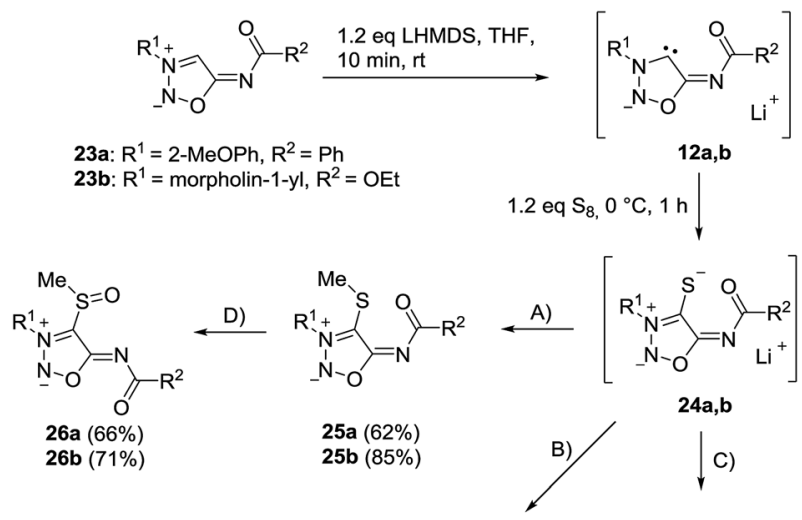

\begin{tabular}{l} 
A) 1.2 eq Mel, $0{ }^{\circ} \mathrm{C}, 0.5 \mathrm{~h}$, \\
then $\mathrm{rt}, 2 \mathrm{~h}$ \\
B) $1.1 \mathrm{AuCIPPh}$ \\
then $\mathrm{rt}, 3 \mathrm{~h}$ \\
C) $0.6 \mathrm{hg}, 0{ }^{\circ} \mathrm{C}$, \\
then $\mathrm{rt}, 16 \mathrm{~h}$ \\
D) $1.1 \mathrm{eq} \mathrm{mCPBA}$, \\
DCM, $-10{ }^{\circ} \mathrm{C}, 3 \mathrm{~h}$ \\
\hline
\end{tabular}
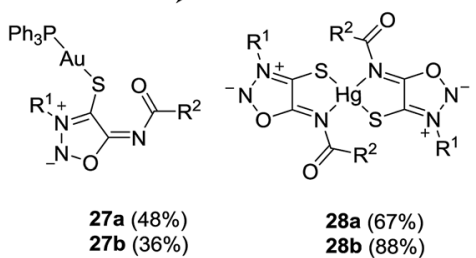

Scheme 5 Trapping reactions of sydnone imines with sulfur and subsequent stabilizations.

The bond between the exocyclic substituent and the sydnone imine is known to be very stable under a variety of reaction conditions. However, the molsidomine derivative 24b surprisingly underwent an intramolecular rearrangement of the morpholinyl group and subsequent nitrogen cleavage for which the depicted mechanism is suggested (Scheme 6). Under analogous reaction conditions, 24a decomposed. Sydnone imine cleavages to form unsaturated nitriles such as $\mathrm{N}$-morpholinoformimidoyl cyanide are known. ${ }^{24}$ They occur, however, when the exocyclic nitrogen atom is not substituted by electron-withdrawing groups. In these cases the $\mathrm{N}-\mathrm{N}$ bond connecting the morpholine group and the sydnone imine remain intact.

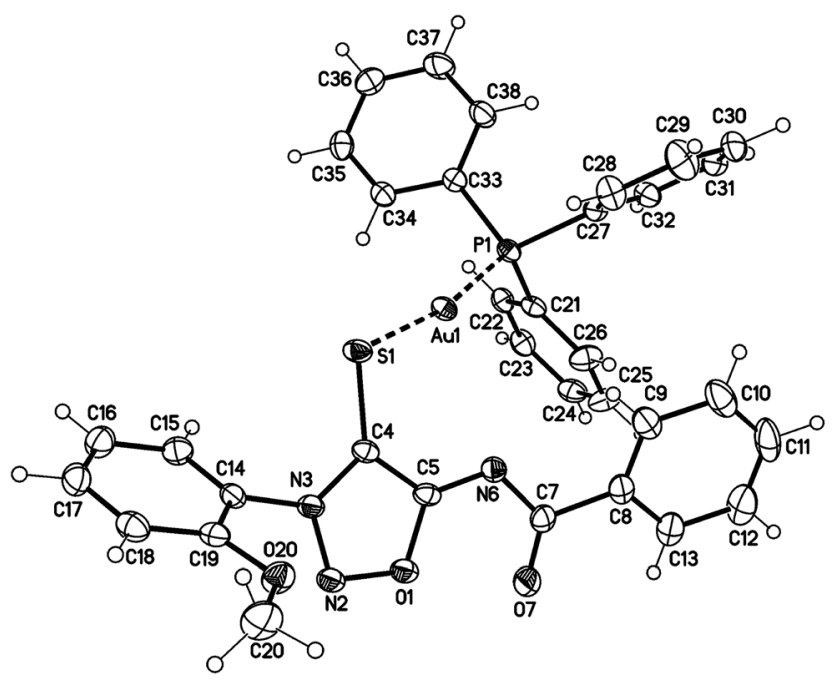

Fig. 1 Molecular drawing of gold complex 27a (displacement parameters are drawn at $50 \%$ probability level). Selected bond lengths [pm] (crystallographic numbering): N2-N3: 132.4(2), N3-C4: 135.6(3), C4-C5: 140.9(3), C5-N6: 130.9(3), N6-C7: 136.8(3), C7-O7: 123.3(3), C4-S1: 172.3(2), S1-Au1: 232.76(5), N6-Au1: 298.97(17), Au1-P1: 225.91(5) pm.

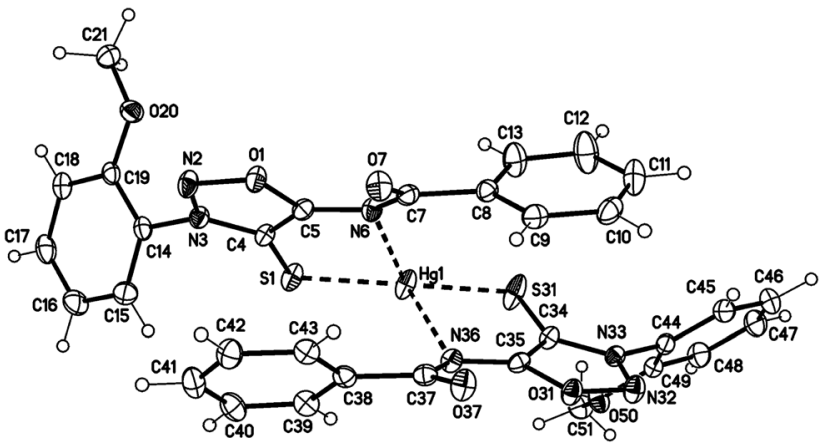

Fig. 2 Molecular drawing of complex 28a (displacement parameters are drawn at $50 \%$ probability level). Selected bond lengths [pm] (crystallographic numbering): N2-N3: 132.5(2), N3-C4: 135.4(3), C4C5: 140.4(3), C5-N6: 132.2(3), N6-C7: 138.5(2), C7-O7: 122.4(2), C4S1: 171.6(2), S1-Hg1: 240.42(6), N6-Hg1: 247.27(17), N32-N33: 132.9(2), N33-C34: 134.8(2), C34-C35: 139.8(3), C35-N36: 132.4(3), N36-C37: 138.1(2), C37-O37: 122.8(2), C34-S31: 171.4(2), S31-Hg1: 239.19(6), N36-Hg1: 251.07(17) pm.

$$
[\underbrace{}_{-\mathrm{LiOH}}
$$

Scheme 6 Morpholinyl group rearrangement starting from molsidomine (23b) via sulfide $24 b$.

We were able to obtain single crystals for an X-ray structure analysis by slow evaporation of $\mathbf{2 9}$ from a saturated solution in ethyl acetate. The structure was confirmed via single crystal Xray analysis (Fig. 3).

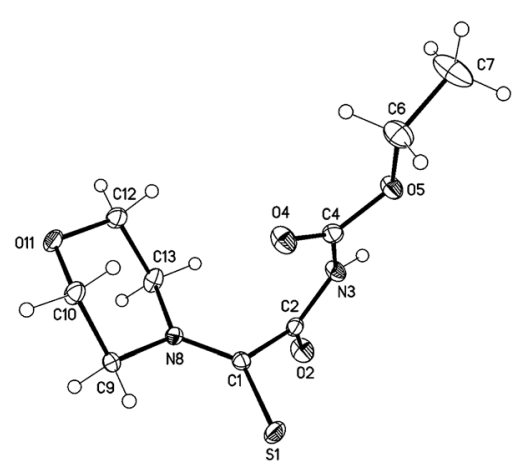

Fig. 3 Molecular drawing of carbamate 29 (displacement parameters are drawn at $50 \%$ probability level). Selected bond lengths [pm] (crystallographic numbering): C1-N8: 131.77(16), C1-S1: 166.56(12), C1-C2: 151.61(16), C2-O2: 121.74(15), C2-N3: 137.07(16), N3-C4: 139.51(16), C4-O4: 120.04(16), S1-H9A: $264 \mathrm{pm}$ 
In comparison to the sydnone imine sulfide mercury(II) complexes we furthermore prepared the transition metal complexes with mercury directly attached to the C4 carbene carbon atom in high yields. These complexes show very high stability towards water, air, bases and higher temperatures. Crystal data show a tetrahedral coordination of the mercury(II) atom (Fig. 4). In comparison to the complex 28a where coordination is observed by the S1 and N6 atom (forming a fivemembered ring), the complex 30a shows coordination by the $\mathrm{C} 4$ and $\mathrm{O} 7$ atom (forming a six-membered ring).

Moreover, we managed to undergo covalent bond formation with triphenyl borane, resulting in a new mesomeric betaine structure in which the negative charge is in the borate substituent (Scheme 7).

The structure was confirmed by a single crystal X-ray analysis (Fig. 5). The molecular drawing shows a tetrahedral arrangement of the covalently bound boron atom. The C4-B22 bond length (165.2(3) pm) (C104-B122 165.6(3) pm) is in agreement

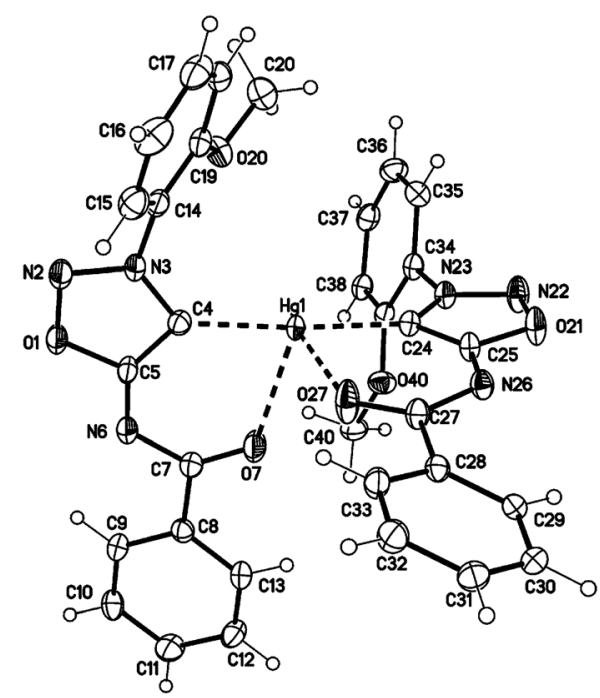

Fig. 4 Molecular drawing of complex 30a (displacement parameters are drawn at $50 \%$ probability level). Selected bond lengths [pm] (crystallographic numbering): N2-N3: 131.3(4), N3-C4: 135.6(4), C4C5: 139.9(5), C5-N6: 131.5(4), N6-C7: 135.5(4), C7-O7: 124.5(4), C4Hg1: 205.0(3), Hg1-O7: 255.1(3), N22-N23: 131.7(4), N23-C24: 135.1(4), C24-C25: 140.2(4), C25-N26: 132.0(4), N26-C27: 135.7(4), C27-O27: 123.8(4), C24-Hg1: 204.6(3), Hg1-O27: 255.2(3) pm.

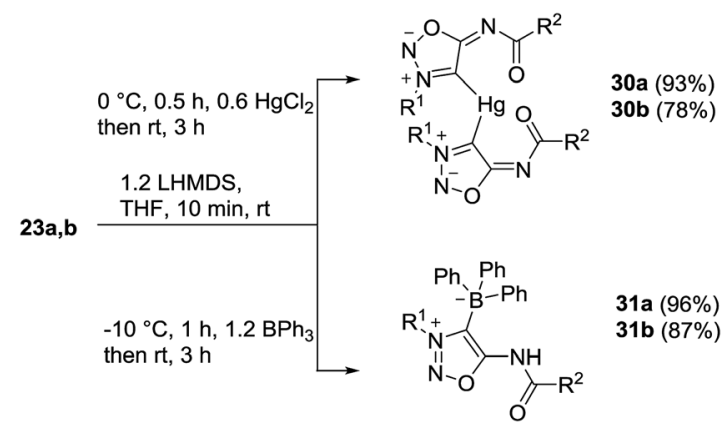

Scheme 7 Reaction of sydnone imines $23 a, b$ with mercury(॥) and triphenylborane.

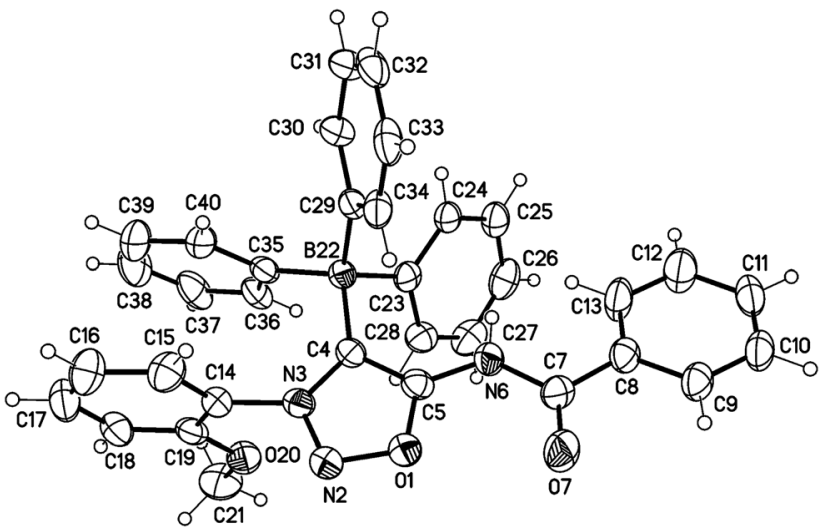

Fig. 5 Molecular drawing of boron compound 31a (one of the two crystallographic independent molecules is shown, displacement parameters are drawn at 50\% probability level). Selected bond lengths [pm] (crystallographic numbering, for the second molecule in brackets): O1-N2: 136.6(2) [135.8(2)], N2-N3: 131.5(2) [130.7(2)], N3C4: 136.8(3) [136.9(3)], C4-C5: 137.9(3) [138.3(3)], O1-C5: 134.7(3) [134.7(2)], C5-N6: 136.1(3) [136.3(3)], N6-C7: 137.7(3) [139.6(3)], C7O7: 121.6(3) [121.7(3)], C4-B22: 165.2(3) [165.6(3)] pm.

with the $\mathrm{Ph}_{4} \mathrm{~B}^{-}$bond length $(164.3 \mathrm{pm})$ presented in the literature. ${ }^{25}$

\section{Experimental}

The reactions were carried out under an atmosphere of nitrogen in oven-dried glassware. Nuclear magnetic resonance (NMR) spectra were obtained with a Bruker Avance 400 and Bruker Avance III $600 \mathrm{MHz} .{ }^{1} \mathrm{H}$ NMR spectra were measured at $400 \mathrm{MHz}$ or $600 \mathrm{MHz}$ and ${ }^{13} \mathrm{C}$ NMR spectra were measured at $100 \mathrm{MHz}$ or $150 \mathrm{MHz}$, with the solvent peak or tetramethylsilane used as the internal reference. Multiplicities are described by using the following abbreviations: $\mathrm{s}=$ singlet, $\mathrm{d}=$ doublet, $\mathrm{t}=$ triplet, $\mathrm{q}=$ quadruplet, and $\mathrm{m}=$ multiplet, and the signal orientations in DEPT experiments were described as follows: $\mathrm{o}=$ no signal; $+=$ up $\left(\mathrm{CH}, \mathrm{CH}_{3}\right) ;-=$ down $\left(\mathrm{CH}_{2}\right)$. ATR-IR spectra were obtained on a Bruker Alpha in the range of 400 to $4000 \mathrm{~cm}^{-1}$. Melting points were measured by differential scanning calorimetry (DSC) using a DSC 6 apparatus (Perkin-Elmer). The HR-MS spectra were measured on a Bruker Daltonik Tesla-Fourier transform-ion cyclotron resonance mass spectrometer with electrospray ionisation. Yields are not optimized.

\section{Crystal structure determinations}

The single-crystal X-ray diffraction study were carried out on a Bruker D8 Venture diffractometer with Photon100 (29) or PhotonII detector (27a, 28a, 30a, 31a) at 123(2) $\mathrm{K}$ using $\mathrm{Cu}-\mathrm{K} \alpha$ radiation $(\lambda=1.54178 \AA)(29,31 \mathrm{a})$ or Mo-K $\alpha$ radiation $(\lambda=$ $0.71073 \AA$ ) $(27 \mathbf{a}, 28 \mathrm{a}, 30 \mathrm{a})$. Dual space/intrinsic methods (27a, 28a, 30a, 31a) (SHELXT) ${ }^{26}$ or direct methods (29) (SHELXS-97) ${ }^{27}$ were used for structure solution and refinement was carried out using SHELXL-2014 (full-matrix least-squares on $F^{2}$ ). ${ }^{26}$ Hydrogen atoms were localized by difference electron density determination and refined using a riding model (in $29 \mathrm{H}(\mathrm{N})$ free). Semi-empirical absorption corrections and extinction 
correction (for 28a, 29) were applied. In 31a refinement with the listed atoms show in one void residual electron density due to a heavily disordered diethylether which could not be refined with split atoms. Therefore the option "SQUEEZE" of the program package PLATON ${ }^{28}$ was used to create a hkl file taking into account the residual electron density in the void areas. Therefore the atoms list and unit card do not agree (see cif-.file for details).

27a: yellow plates, $\mathrm{C}_{34} \mathrm{H}_{27} \mathrm{~N}_{3} \mathrm{O}_{3} \mathrm{SPAu}, M=785.58$, crystal size $0.10 \times 0.05 \times 0.02 \mathrm{~mm}$, triclinic, space group $P \overline{1}$ (no. 2 ), $a=$

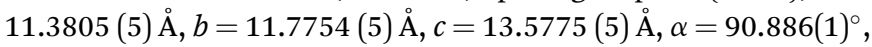
$\beta=114.586(1)^{\circ}, \gamma=112.289(1)^{\circ}, V=1498.12(11) \AA^{3}, Z=2$, $\rho($ calc $)=1.742 \mathrm{Mg} \mathrm{m}^{-3}, F(000)=772, \mu(\mathrm{MoK} \alpha)=5.07 \mathrm{~mm}^{-1}$, 43043 reflections $\left(2 \theta_{\max }=55.0^{\circ}\right), 6890$ unique $\left[R_{\text {int }}=0.034\right]$, 389 parameters, $R_{1}$ (for $\left.6512 I>2 \sigma(I)\right)=0.016, w R 2$ (all data) $=$ 0.036, $S=1.07$, largest diff. peak and hole 0.75 and $-0.47 \mathrm{e}^{-3}$.

28a: yellow blocks, $\mathrm{C}_{32} \mathrm{H}_{24} \mathrm{~N}_{6} \mathrm{O}_{6} \mathrm{~S}_{2} \mathrm{Hg}, M=853.28$, crystal size $0.16 \times 0.10 \times 0.04 \mathrm{~mm}$, triclinic, space group $P \overline{1}$ (no. 2), $a=$ 8.5954(11) $\mathrm{A}, b=11.3147(14) \AA, c=17.4308(19) \AA, \alpha=$ $77.613(4)^{\circ}, \beta=86.366(4)^{\circ}, \gamma=70.249(4)^{\circ}, V=1558.3(3) \AA^{3}, Z=$ $2, \rho($ calc $)=1.819 \mathrm{Mg} \mathrm{m}^{-3}, F(000)=836, \mu(\mathrm{MoK} \alpha)=5.13 \mathrm{~mm}^{-1}$, 38298 reflections $\left(2 \theta_{\max }=55.0^{\circ}\right), 7157$ unique $\left[R_{\text {int }}=0.031\right]$, 427 parameters, $R_{1}$ (for $\left.6733 I>2 \sigma(I)\right)=0.018, w R 2$ (all data) $=$ $0.037, S=1.08$, largest diff. peak and hole 0.71 and $-0.67 \mathrm{e \AA}^{-3}$.

29: colourless blocks, $\mathrm{C}_{9} \mathrm{H}_{14} \mathrm{~N}_{2} \mathrm{O}_{4} \mathrm{~S}, M=246.28$, crystal size $0.45 \times 0.35 \times 0.15 \mathrm{~mm}$, monoclinic, space group $C 2 / c$ (no. 15), $a=23.9648(12) \AA, b=6.5378(3) \AA, c=14.6598(8) \AA, \beta=$ 92.902(1) $)^{\circ}, V=2293.9(2) \AA^{3}, Z=8, \rho($ calc $)=1.426 \mathrm{Mg} \mathrm{m}^{-3}$, $F(000)=1040, \mu(\mathrm{CuK} \alpha)=2.56 \mathrm{~mm}^{-1}, 14352$ reflections $\left(2 \theta_{\max }\right.$ $\left.=144.4^{\circ}\right), 2240$ unique $\left[R_{\mathrm{int}}=0.023\right], 149$ parameters, 1 restraint, $R_{1}($ for $2230 I>2 \sigma(I))=0.029, w R 2$ (all data) $=0.073, S$ $=1.09$, largest diff. peak and hole 0.36 and $-0.27 \mathrm{e}^{-3}$.

30a: colourless blocks, $\mathrm{C}_{32} \mathrm{H}_{24} \mathrm{~N}_{6} \mathrm{O}_{6} \mathrm{Hg}, M=789.16$, crystal size $0.04 \times 0.02 \times 0.01 \mathrm{~mm}$, triclinic, space group $P \overline{1}$ (no. 2), $a=$ $10.4627(5) \AA, \quad b=11.4660(6) \AA, c=13.4682(7) \AA, \alpha=79.335(2)^{\circ}$, $\beta=68.151(2)^{\circ}, \gamma=89.637(2)^{\circ}, V=1470.28(13) \AA^{3}, Z=2, \rho($ calc $)$ $=1.783 \mathrm{Mg} \mathrm{m}^{-3}, F(000)=772, \mu(\mathrm{MoK} \alpha)=5.29 \mathrm{~mm}^{-1}, 55028$ reflections $\left(2 \theta_{\max }=55.0^{\circ}\right), 6727$ unique $\left[R_{\mathrm{int}}=0.044\right], 408$ parameters, $R_{1}$ (for $\left.6372 I>2 \sigma(I)\right)=0.024, w R 2$ (all data) $=$ $0.050, S=1.19$, largest diff. peak and hole 1.66 and $-2.23 \mathrm{e}^{-3}$.

31a: colourless plates, $\mathrm{C}_{34} \mathrm{H}_{28} \mathrm{BN}_{3} \mathrm{O}_{3} \cdot 0.25\left(\mathrm{C}_{4} \mathrm{H}_{10} \mathrm{O}\right), M=$ 555.93 , crystal size $0.20 \times 0.12 \times 0.06 \mathrm{~mm}$, triclinic, space

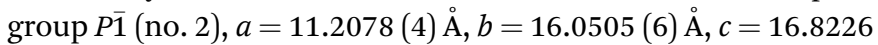
(7) $\AA, \alpha=74.625(2)^{\circ}, \beta=88.792(2)^{\circ}, \gamma=85.859(2)^{\circ}, 2910.3$ (2) $\AA^{3}, Z=4, \rho($ calc $)=1.269 \mathrm{Mg} \mathrm{m}^{-3}, F(000)=1170, \mu(\mathrm{CuK} \alpha)=0.65$ $\mathrm{mm}^{-1}, 38234$ reflections $\left(2 \theta_{\max }=144.4^{\circ}\right), 11373$ unique $\left[R_{\mathrm{int}}=\right.$ 0.038], 741 parameters, $R_{1}$ (for $\left.9893 I>2 \sigma(I)\right)=0.060, w R 2$ (all data) $=0.172, S=1.04$, largest diff. peak and hole 0.46 and $-0.28 \mathrm{e}^{-3}$.

\section{Synthesis}

6-Benzoyl-3-(2-methoxyphenyl)-4-methylthio-sydnone imine (25a). $0.30 \mathrm{~g}$ (1.0 mmol) of 6-benzoyl-3-(2-methoxyphenyl)sydnone imine are dissolved in $12 \mathrm{~mL}$ THF (abs.) under an inert atmosphere. Then $1.20 \mathrm{~mL}(1.2 \mathrm{mmol})$ of LHMDS (1 $\mathrm{M}$ in THF) are added at rt. The mixture is cooled to $0{ }^{\circ} \mathrm{C}$ treated with
$0.04 \mathrm{~g}(1.2 \mathrm{mmol})$ of sulfur and stirred for $1 \mathrm{~h}$. Then $0.08 \mathrm{~mL}(1.2$ $\mathrm{mmol}$ ) of $\mathrm{MeI}$ are added. After stirring for 30 minutes at $0{ }^{\circ} \mathrm{C}$ the flask is warmed up to rt and stirred for another $2 \mathrm{~h}$. The crude product is purified by column chromatography (DCM : $\mathrm{MeOH}$ 40 : 1). Yield: $0.21 \mathrm{~g}(62 \%)$ of a yellow solid, $\mathrm{mp} 248{ }^{\circ} \mathrm{C}$ (decomp.). ${ }^{1} \mathrm{H}-\mathrm{NMR}\left(400 \mathrm{MHz}, \mathrm{CDCl}_{3}\right): \delta=8.33-8.35$ (m, 2H, 9/ 9'-H), 7.65-7.69 (m, 1H, 15-H), 7.47-7.51 (m, 1H, 11-H), 7.41$7.46\left(\mathrm{~m}, 3 \mathrm{H}, 10 / 10^{\prime}-\mathrm{H}+17-\mathrm{H}\right), 7.21-7.16(\mathrm{~m}, 2 \mathrm{H}, 16-\mathrm{H}+14-\mathrm{H})$, 3.90 (s, 3H, 19-H), 2.47 (s, 3H, 21-H) ppm; ${ }^{13} \mathrm{C}-\mathrm{NMR}(100 \mathrm{MHz}$, $\mathrm{CDCl}_{3}$ ): $\delta=172.8$ (o, C-7), 167.2 (o, C-5), 153.5 (o, C-13), 137.3 (o, C-8), $134.1(+, \mathrm{C}-15), 131.4(+, \mathrm{C}-11), 129.6\left(+, \mathrm{C}-9 / 9^{\prime}\right), 127.9(+, \mathrm{C}-$ 10/10'), 127.1 (+, C-17), 121.7 (o, C-12), 121.1 (+, C-16), 114.2 (o, C-4), 112.6 (+, C-14), 56.1 (+, C-19), 7.4 (+, C-21) ppm; IR (ATR): 3057, 2928, 2842, 1558, 1499, 1353, 1286, 1218, 1159, 1087, 1017, 794, 754, 706, $529 \mathrm{~cm}^{-1}$; HR-ESI-MS: calcd for $\mathrm{C}_{17} \mathrm{H}_{16} \mathrm{~N}_{3} \mathrm{O}_{3} \mathrm{~S}^{+}$342.0912. Found 342.0915.

6-Ethoxycarbonyl-4-methylthio-3-morpholinyl-sydnone

imine (25b). $0.50 \mathrm{~g}$ (2.1 mmol) 6-ethoxycarbonyl-3-morpholinylsydnone imine are dissolved in $18 \mathrm{~mL}$ THF (abs.) under an inert atmosphere. Then $2.27 \mathrm{~mL}$ (2.3 mmol) of LHMDS ( $1 \mathrm{M}$ in THF) are added at $\mathrm{rt}$. The mixture is cooled to $0{ }^{\circ} \mathrm{C}$, treated with $0.08 \mathrm{~g}$ $(2.5 \mathrm{mmol})$ of sulfur and stirred for $1 \mathrm{~h}$. Then $0.16 \mathrm{~mL}(2.5$ $\mathrm{mmol}$ ) of MeI are added. After stirring for 30 minutes at $0{ }^{\circ} \mathrm{C}$ the flask is warmed up to rt and stirred for another $2 \mathrm{~h}$. The crude product is purified by column chromatography (EE). Yield: $0.51 \mathrm{~g}(85 \%)$ of a white solid, mp $137{ }^{\circ} \mathrm{C}, 224{ }^{\circ} \mathrm{C}$ (decomp.). ${ }^{1} \mathrm{H}$ NMR (400 MHz, $\mathrm{CDCl}_{3}$ ): $\delta=4.20\left(\mathrm{q}, 2 \mathrm{H},{ }^{3} J_{\mathrm{H}, \mathrm{H}}=7.1 \mathrm{~Hz}, 9-\mathrm{H}\right)$, 3.96-3.99 (m, 4H, 13/13'-H), 3.51-3.54 (m, 4H, 12/12'-H), 2.46 (s, $3 \mathrm{H}, 16-\mathrm{H}), 1.32\left(\mathrm{t}, 3 \mathrm{H},{ }^{3} J_{\mathrm{H}, \mathrm{H}}=7.1 \mathrm{~Hz}, 10-\mathrm{H}\right) \mathrm{ppm} ;{ }^{13} \mathrm{C}-\mathrm{NMR}(100$ $\mathrm{MHz}, \mathrm{CDCl}_{3}$ ): $\delta=167.2$ (o, C-5), 159.3 (o, C-7), 105.9 (o, C-4), $65.9\left(-, \mathrm{C}-13 / 13^{\prime}\right), 61.3$ (-, C-9), 55.2 (-, C-12/12'), 16.6 (+, C16), 14.4 (+, C-10) ppm; IR (ATR): 2973, 2931, 2901, 2858, 1660, 1595, 1408, 1368, 1290, 1260, 1204, 1102, 1049, 977, 878, $790,722,655, \quad 557,504 \mathrm{~cm}^{-1}$; HR-ESI-MS: calcd for $\mathrm{C}_{10} \mathrm{H}_{17} \mathrm{~N}_{4} \mathrm{O}_{4} \mathrm{~S}^{+} 289.0971$. Found 289.0970.

6-Benzoyl-3-(2-methoxyphenyl)-4-methylsulfinyl-sydnone imine (26a). $0.27 \mathrm{~g}$ (0.8 mmol) 6-benzoyl-3-(2-methoxyphenyl)-4methylthio-sydnone imine are dissolved in $15 \mathrm{~mL}$ DCM at $-10{ }^{\circ} \mathrm{C}$, then $0.21 \mathrm{~g}(0.9 \mathrm{mmol})$ of $m$-chloroperbenzoic acid (77 $\mathrm{w} \%$ ) are added. The mixture is stirred for $3 \mathrm{~h}$ at $-10{ }^{\circ} \mathrm{C}$ and treated with a saturated $\mathrm{NaHCO}_{3}$ solution in water. The organic layer is separated. Then the water layer is extracted $3 \times$ with DCM and dried over $\mathrm{MgSO}_{4}$. The crude product is purified by column chromatography (EE : PE $1: 1)$. Yield: $0.19 \mathrm{~g}(66 \%)$ of a white solid, mp $158{ }^{\circ} \mathrm{C}, 185{ }^{\circ} \mathrm{C}$ (decomp.). ${ }^{1} \mathrm{H}-\mathrm{NMR}(400 \mathrm{MHz}$, $\left.\mathrm{CDCl}_{3}\right): \delta=8.28-8.31\left(\mathrm{~m}, 2 \mathrm{H}, 9 / 9^{\prime}-\mathrm{H}\right), 7.67-7.71(\mathrm{~m}, 1 \mathrm{H}, 15-\mathrm{H})$, 7.49-7.57 (m, 2H, 11/17-H), 7.42-7.46 (m, 2H, 10/10'-H), 7.217.16 (m, 2H, 16/14-H), 3.94 (s, 3H, 19-H), 3.37 (s, 3H, 21-H) ppm; ${ }^{13} \mathrm{C}-\mathrm{NMR}\left(100 \mathrm{MHz}, \mathrm{CDCl}_{3}\right.$ ): $\delta=173.0$ (o, C-7), 163.8 (o, C-5), 153.0 (o, C-13), 136.3 (o, C-8), 134.7 (+, C-15), 132.0 (+, C-11), 129.8 (+, C-9/9'), 128.0 (+, C-10/10'), 127.1 (+, C-17), $121.4(+$, C-16), 121.0 (o, C-12), 117.3 (o, C-4), 112.6 (+, C-14), 56.3 (+, C19), $37.6(+, \mathrm{C}-21) \mathrm{ppm}$; IR (ATR): 3062, 3023, 2948, 1642, 1573, 1498, 1467, 1354, 1313, 1285, 1275, 1234, 1159, 1060, 1034, 1017, 982, 939, 807, 753, 706, 681, 586, 530, 474, $422 \mathrm{~cm}^{-1}$; HR-ESI-MS: calcd for $\mathrm{C}_{17} \mathrm{H}_{15} \mathrm{~N}_{3} \mathrm{O}_{4} \mathrm{SNa}^{+}$380.0681. Found 380.0680 . 
6-Ethoxycarbonyl-4-methylsulfinyl-3-morpholinyl-sydnone imine (26b). $0.11 \mathrm{~g} \quad(0.4 \mathrm{mmol})$ of 6-ethoxycarbonyl-4methylthio-3-morpholinyl-sydnone imine are dissolved in $10 \mathrm{~mL}$ DCM at $-10{ }^{\circ} \mathrm{C}$, then $0.07 \mathrm{~g}(0.4 \mathrm{mmol})$ of $m$-chloroperbenzoic acid $(77 \mathrm{w} \%)$ are added. The mixture is stirred for $3 \mathrm{~h}$ at $-10{ }^{\circ} \mathrm{C}$ and treated with a saturated $\mathrm{NaHCO}_{3}$ solution in water. The organic layer is separated. Then the water layer is extracted $3 \times$ with $\mathrm{DCM}$ and dried over $\mathrm{MgSO}_{4}$. The crude product is purified by column chromatography (EE : $\mathrm{MeOH}$ 20 : 1). Yield: $0.08 \mathrm{~g}$ (71\%) of a white solid, $\mathrm{mp} 158{ }^{\circ} \mathrm{C}$ (decomp.). ${ }^{1} \mathrm{H}-\mathrm{NMR}\left(400 \mathrm{MHz}, \mathrm{CDCl}_{3}\right.$ ): $\delta=4.15-4.27$ (m, 2H, 9-H), 3.974.00 (m, 4H, 13/13'-H), 3.56-3.65 (m, 4H, 12/12'-H), 3.30 (s, 3H, $16-\mathrm{H}), 1.33\left(\mathrm{t}, 3 \mathrm{H},{ }^{3} \mathrm{~J}_{\mathrm{H}, \mathrm{H}}=7.1 \mathrm{~Hz}, 10-\mathrm{H}\right) \mathrm{ppm} ;{ }^{13} \mathrm{C}-\mathrm{NMR}(100$ $\mathrm{MHz}, \mathrm{CDCl}_{3}$ ): $\delta=162.8$ (o, C-5), 158.8 (o, C-7), 111.5 (o, C-4), $66.1\left(-, \mathrm{C}-13 / 13^{\prime}\right), 62.0(-, \mathrm{C}-9), 56.7\left(-, \mathrm{C}-12 / 12^{\prime}\right), 36.3(+, \mathrm{C}-$ 16), 14.4 (+, C-10) ppm; IR (ATR): 2986, 2914, 2865, 1670, 1607, 1406, 1367, 1299, 1255, 1206, 1147, 1103, 1042, 980, 942, 881, 798, 759, 719, 638, 560, 485, $443 \mathrm{~cm}^{-1}$; HR-ESI-MS: calcd for $\mathrm{C}_{10} \mathrm{H}_{16} \mathrm{~N}_{4} \mathrm{O}_{5} \mathrm{SNa}^{+}$289.0739. Found 327.0738.

((6-Benzoyl-3-(2-methoxyphenyl)-sydnone imine-4-yl)thio)(triphenylphosphine)-gold(I) (27a). $0.075 \mathrm{~g}(0.25 \mathrm{mmol})$ of 6benzoyl-3-(2-methoxyphenyl)-sydnone imine are dissolved in $8 \mathrm{~mL}$ of THF (abs.) under an inert atmosphere. Then $0.30 \mathrm{~mL}$ ( $0.30 \mathrm{mmol})$ of LHMDS ( $1 \mathrm{M}$ in THF) are added at rt. The mixture is cooled to $0{ }^{\circ} \mathrm{C}$, treated with $0.001 \mathrm{~g}(0.30 \mathrm{mmol})$ of sulfur and stirred for $2.5 \mathrm{~h}$. Then $0.150 \mathrm{~g}(0.30 \mathrm{mmol})$ of $\mathrm{AuCl}\left(\mathrm{PPh}_{3}\right)$ are added. After stirring for 30 minutes at $0{ }^{\circ} \mathrm{C}$ the flask is warmed up to rt and stirred for another $3 \mathrm{~h}$. The crude product is purified by column chromatography (PE : EE $1: 2$ ). Yield: $0.096 \mathrm{~g}$ (48\%) of a yellow solid, mp $199{ }^{\circ} \mathrm{C}$ (decomp.). ${ }^{1} \mathrm{H}$ NMR (600 MHz, $\left.\mathrm{CDCl}_{3}\right): \delta=8.24-8.26\left(\mathrm{~m}, 2 \mathrm{H}, 9 / 9^{\prime}-\mathrm{H}\right), 7.57-7.60$ (m, 1H, 15-H), 7.37-7.44 (m, 10H, 24/24'-H + 26- $\mathrm{H}+17-\mathrm{H}), 7.31-$ $7.33\left(\mathrm{~m}, 6 \mathrm{H}, 25 / 25^{\prime}-\mathrm{H}\right), 7.11-7.14(\mathrm{~m}, 2 \mathrm{H}, 14-\mathrm{H}+16-\mathrm{H}), 7.05-7.08$ $(\mathrm{m}, 1 \mathrm{H}, 11-\mathrm{H}), 6.78-6.81\left(\mathrm{~m}, 2 \mathrm{H}, 10 / 10^{\prime}-\mathrm{H}\right), 3.88(\mathrm{~s}, 3 \mathrm{H}, 19-$ H) ppm; ${ }^{13} \mathrm{C}-\mathrm{NMR}\left(150 \mathrm{MHz}, \mathrm{CDCl}_{3}\right): \delta=172.9$ (o, C-7), 168.6 (o, C-5), 154.1 (o, C-13), 137.9 (o, C-8), 134.1 (+, d, ${ }^{2} J_{\mathrm{C}, \mathrm{P}}=14.0 \mathrm{~Hz}, \mathrm{C}-$ 24/24'), $133.3(+, \mathrm{C}-15), 131.5\left(+, \mathrm{d},{ }^{4} J_{\mathrm{C}, \mathrm{P}}=1.7 \mathrm{~Hz}, \mathrm{C}-26\right), 130.3(+$, C-11), 129.4 (+, C-9/9'), 129.2 (o, d, $\left.{ }^{1} J_{\mathrm{C}, \mathrm{P}}=55.5 \mathrm{~Hz}, \mathrm{C}-23\right), 129.0$ $\left(+, \mathrm{d},{ }^{3} J_{\mathrm{C}, \mathrm{P}}=11.8 \mathrm{~Hz}, \mathrm{C}-25 / 25^{\prime}\right), 127.8(+, \mathrm{C}-17), 127.2(+, \mathrm{C}-10 /$ 10'), 125.7 (o, C-4), 122.6 (o, C-12), 120.8 (+, C-16), 112.8 (+, C14), 56.1 (+, C-19) ppm; ${ }^{31} \mathrm{P}-\mathrm{NMR}:\left(243 \mathrm{MHz}, \mathrm{CDCl}_{3}\right): \delta=$ 36.6 ppm; IR (ATR): 3052, 2966, 2863, 1608, 1555, 1503, 1435, 1359, 1292, 1253, 1159, 1099, 1043, 1019, 996, 906, 744, 692, 539, $496 \mathrm{~cm}^{-1}$; HR-ESI-MS: calcd for $\mathrm{C}_{34} \mathrm{H}_{27} \mathrm{~N}_{3} \mathrm{O}_{3} \mathrm{SAuPNa}^{+}$ 808.1074. Found 808.1070.

((6-Ethoxycarbonyl-3-morpholinyl-sydnone imine-4-yl)thio)(triphenylphosphine)-gold(I) (27b). $0.061 \mathrm{~g}(0.25 \mathrm{mmol})$ of 6ethoxycarbonyl-3-morpholinyl sydnone imine are dissolved in $8 \mathrm{~mL}$ of THF (abs.) under an inert atmosphere. Then $0.30 \mathrm{~mL}$ ( $0.30 \mathrm{mmol})$ of LHMDS ( $1 \mathrm{M}$ in THF) are added at rt. The mixture is cooled to $0{ }^{\circ} \mathrm{C}$, treated with $0.001 \mathrm{~g}(0.30 \mathrm{mmol})$ of sulfur and stirred for $2.5 \mathrm{~h}$. Then $0.150 \mathrm{~g}(0.30 \mathrm{mmol})$ of $\mathrm{AuCl}\left(\mathrm{PPh}_{3}\right)$ are added. After stirring for 30 minutes at $0{ }^{\circ} \mathrm{C}$ the flask is warmed up to rt and stirred for another $3 \mathrm{~h}$. The crude product is purified by column chromatography (PE : EE $1: 2$ ). Yield: $0.067 \mathrm{~g}(36 \%)$ of a yellow solid, mp $155{ }^{\circ} \mathrm{C}$ (decomp.). ${ }^{1} \mathrm{H}-$
NMR (600 MHz, $\left.\mathrm{CDCl}_{3}\right): \delta=7.60\left(\mathrm{~m}, 6 \mathrm{H}, 19 / 19^{\prime}-\mathrm{H}\right), 7.48-7.50$ (m, 3H, 21-H), 7.42-7.45 (m, 6H, 20/20'-H), 3.93-3.94 (m, 4H, 13/ $\left.13^{\prime}-\mathrm{H}\right), 3.73\left(\mathrm{q}, 2 \mathrm{H},{ }^{3} J_{\mathrm{H}, \mathrm{H}}=7.1 \mathrm{~Hz}, 9-\mathrm{H}\right), 3.51-3.53(\mathrm{~m}, 4 \mathrm{H}, 12 /$ $\left.12^{\prime}-\mathrm{H}\right), 0.76\left(\mathrm{t}, 3 \mathrm{H},{ }^{3} J_{\mathrm{H}, \mathrm{H}}=7.1 \mathrm{~Hz}, 10-\mathrm{H}\right) \mathrm{ppm} ;{ }^{13} \mathrm{C}-\mathrm{NMR}(150$ $\left.\mathrm{MHz}, \mathrm{CDCl}_{3}\right): \delta=169.1$ (o, C-5), 159.8 (o, C-7), $134.3\left(+, \mathrm{d},{ }^{2} J_{\mathrm{C}, \mathrm{P}}=\right.$ $14.1 \mathrm{~Hz}, \mathrm{C}-19 / 19^{\prime}$ ), 131.4 (+, C-21), 130.0 (o, d, ${ }^{1} J_{\mathrm{C}, \mathrm{P}}=57.5 \mathrm{~Hz}, \mathrm{C}-$ 18), $128.9\left(+, \mathrm{d},{ }^{3} J_{\mathrm{C}, \mathrm{P}}=11.7 \mathrm{~Hz}, \mathrm{C}-20 / 20^{\prime}\right), 119.4$ (o, C-4), 66.1 (-, C-13/13'), 60.4 (-, C-9), 53.5 (-, C-12/12'), 14.1 (+, C-10) ppm; ${ }^{31}$ P-NMR: (243 MHz, $\mathrm{CDCl}_{3}$ ): $\delta=36.6$ ppm; IR (ATR): 2972, 2859, 1659, 1593, 1239, 1180, 1100, 1070, 879, 746, 692, 537, $508 \mathrm{~cm}^{-1}$; HR-ESI-MS: calcd for $\mathrm{C}_{27} \mathrm{H}_{28} \mathrm{~N}_{4} \mathrm{O}_{4} \mathrm{SAuPNa}^{+}$755.1132. Found 755.1124 .

(Bis(6-benzoyl-3-(2-methoxyphenyl)-sydnone imine-4-yl)thio) mercury(II) (28a). $0.15 \mathrm{~g} \quad(0.5 \mathrm{mmol})$ of 6-benzoyl-3-(2methoxyphenyl)-sydnone imine are dissolved in $10 \mathrm{~mL}$ of THF (abs.) under an inert atmosphere. Then $0.60 \mathrm{~mL}(0.6 \mathrm{mmol})$ of LHMDS ( $1 \mathrm{M}$ in THF) are added at rt. The mixture is cooled to $0{ }^{\circ} \mathrm{C}$, treated with $0.02 \mathrm{~g}(0.6 \mathrm{mmol})$ of sulfur and stirred for $2.5 \mathrm{~h}$. Then $0.08 \mathrm{~g}(0.3 \mathrm{mmol})$ of $\mathrm{HgCl}_{2}$ are added. After stirring for 30 minutes at $0{ }^{\circ} \mathrm{C}$ the flask is warmed up to rt and stirred for another $3 \mathrm{~h}$. The crude product is purified by column chromatography (PE : EE : DCM $2: 4: 1)$. Yield: $0.14 \mathrm{~g}(67 \%)$ of a yellow solid, mp $189{ }^{\circ} \mathrm{C}$ (decomp.). ${ }^{1} \mathrm{H}-\mathrm{NMR}\left(600 \mathrm{MHz}, \mathrm{CDCl}_{3}\right): \delta=$ 8.05-8.07 (m, 2H, 9/9'-H), 7.62-7.65 (m, 1H, 15-H), 7.38-7.40 (m, $1 \mathrm{H}, 11-\mathrm{H}), 7.24-7.27\left(\mathrm{~m}, 3 \mathrm{H}, 10 / 10^{\prime}-\mathrm{H}+17-\mathrm{H}\right), 7.15-7.18(\mathrm{~m}, 1 \mathrm{H}$, 16-H), 7.13-7.15 (m, 1H, 14-H), 3.82 (s, 3H, 19-H) ppm; ${ }^{13} \mathrm{C}-\mathrm{NMR}$ $\left(150 \mathrm{MHz}, \mathrm{CDCl}_{3}\right): \delta=173.4$ (o, C-7), 168.9 (o, C-5), 153.6 (o, C13), 137.1 (o, C-8), 134.0 (+, C-15), 130.8 (+, C-11), 129.2 (+, C-9/ 9'), $127.6\left(+, \mathrm{C}-10 / 10^{\prime}\right), 127.2$ (+, C-17), 126.0 (o, C-4), 121.5 (o, C12), 121.0 (+, C-16), 113.0 (+, C-14), 56.1 (+, C-19) ppm; IR (ATR): 3057, 2841, 1629, 1546, 1500, 1366, 1287, 1198, 1162, 1121, 1055, 1014, 912, 760, 718, 696, $537 \mathrm{~cm}^{-1}$; HR-ESI-MS: calcd for $\mathrm{C}_{32} \mathrm{H}_{24} \mathrm{~N}_{6} \mathrm{O}_{6} \mathrm{~S}_{2} \mathrm{HgNa}^{+}$877.0797. Found 877.0764.

Bis((6-ethoxycarbonyl-3-morpholinyl-sydnone imine-4-yl) thio)mercury(II) (28b). $0.12 \mathrm{~g}$ (0.5 mmol) of 6-ethoxycarbonyl-3morpholinyl-sydnone imine are dissolved in $10 \mathrm{~mL}$ of THF (abs.) under an inert atmosphere. Then $0.60 \mathrm{~mL}(0.6 \mathrm{mmol})$ of LHMDS ( $1 \mathrm{M}$ in THF) are added at rt. The mixture is cooled to $0{ }^{\circ} \mathrm{C}$ treated with $0.02 \mathrm{~g}(0.6 \mathrm{mmol})$ of sulfur and stirred for $2.5 \mathrm{~h}$. Then $0.08 \mathrm{~g}(0.3 \mathrm{mmol})$ of $\mathrm{HgCl}_{2}$ are added. After stirring for 30 minutes at $0{ }^{\circ} \mathrm{C}$ the flask is warmed up to rt and stirred for another $3 \mathrm{~h}$. Formation of a yellow precipitate is observed. The solid is filtered off and washed with THF and $\mathrm{Et}_{2} \mathrm{O}$. Yield: $0.16 \mathrm{~g}$ (88\%) of a yellow solid, mp $179{ }^{\circ} \mathrm{C}$ (decomp.). ${ }^{1} \mathrm{H}$-NMR (600 $\left.\mathrm{MHz}, \mathrm{CDCl}_{3}\right): \delta=4.01\left(\mathrm{q}, 2 \mathrm{H},{ }^{3} J_{\mathrm{H}, \mathrm{H}}=7.1 \mathrm{~Hz}, 9-\mathrm{H}\right), 3.99-4.00(\mathrm{~m}$, $\left.4 \mathrm{H}, 13 / 13^{\prime}-\mathrm{H}\right), 3.56-3.58\left(\mathrm{~m}, 4 \mathrm{H}, 12 / 12^{\prime}-\mathrm{H}\right), 1.01\left(\mathrm{t}, 3 \mathrm{H},{ }^{3} J_{\mathrm{H}, \mathrm{H}}=\right.$ $7.1 \mathrm{~Hz}, 10-\mathrm{H}) \mathrm{ppm} ;{ }^{13} \mathrm{C}-\mathrm{NMR}\left(150 \mathrm{MHz}, \mathrm{CDCl}_{3}\right): \delta=168.4(\mathrm{o}, \mathrm{C}-$ 5), 157.4 (o, C-7), 119.2 (o, C-4), 66.0 (-, C-13/13'), 61.3 (-, C-9), 53.7 (-, C-12/12'), 14.1 (+, C-10) ppm; IR (ATR): 2977, 2924, 2900, 2871, 1671, 1596, 1432, 1365, 1289, 1248, 1191, 1089, 1021, 983, 879, 772, 724, 610, 593, 561, $511 \mathrm{~cm}^{-1}$; HR-ESI-MS: calcd for $\mathrm{C}_{18} \mathrm{H}_{26} \mathrm{~N}_{8} \mathrm{O}_{8} \mathrm{~S}_{2} \mathrm{HgNa}^{+}$771.0919. Found 771.0916.

Ethyl- $\boldsymbol{N}$-(1-morpholinyl-1-thioxo-ethan-2-one)-carbamate (29). $0.24 \mathrm{~g}$ (1.0 mmol) of 6-ethoxycarbonyl-3-morpholinylsydnone imine are dissolved in $10 \mathrm{~mL}$ of THF (abs.) under an inert atmosphere. Then $1.20 \mathrm{~mL}(1.2 \mathrm{mmol})$ of LHMDS ( $1 \mathrm{M}$ in THF) are added at rt. The mixture is cooled to $0{ }^{\circ} \mathrm{C}$, treated with 
$0.04 \mathrm{~g}(1.2 \mathrm{mmol})$ of sulfur and stirred for $2 \mathrm{~h}$. Then $1 \mathrm{~mL}$ of water is added. After stirring for 30 minutes the solvent is removed under removed pressure. The crude product is purified by column chromatography (EE). Yield: $0.15 \mathrm{~g}$ (63\%) of a yellow solid, mp $134{ }^{\circ} \mathrm{C} .{ }^{1} \mathrm{H}-\mathrm{NMR}\left(400 \mathrm{MHz}, \mathrm{CDCl}_{3}\right): \delta=8.43$ (br. s, $1 \mathrm{H}$, $3-\mathrm{H}), 4.26\left(\mathrm{q}, 2 \mathrm{H},{ }^{3} \mathrm{~J}_{\mathrm{H}, \mathrm{H}}=7.1 \mathrm{~Hz}, 6-\mathrm{H}\right), 4.18-4.20\left(\mathrm{~m}, 2 \mathrm{H}, 9-\mathrm{H} / 9^{\prime}-\right.$ $\mathrm{H}), 3.85-3.88\left(\mathrm{~m}, 2 \mathrm{H}, 10-\mathrm{H} / 10^{\prime}-\mathrm{H}\right), 3.78-3.81\left(\mathrm{~m}, 2 \mathrm{H}, 10-\mathrm{H} / 10^{\prime}-\right.$ $\mathrm{H})$, 3.71-3.74 (m, 2H, 9-H/9'-H), $1.32\left(\mathrm{t}, 3 \mathrm{H},{ }^{3} J_{\mathrm{H}, \mathrm{H}}=7.1 \mathrm{~Hz}, 7-\right.$ H) ppm; ${ }^{13} \mathrm{C}-\mathrm{NMR}\left(100 \mathrm{MHz}, \mathrm{CDCl}_{3}\right): \delta=189.3$ (o, C-1), 163.6 (o, C-2), 150.7 (o, C-4), 65.9 (-, C-10/C-10'), 65.8 (-, C-10/C-10'), 63.0 (-, C-6), 52.3 (-, C-9/C-9'), 47.3 (-, C-9/C-9'), 14.1 (+, C7) ppm; IR (ATR): 3126, 2938, 2873, 1760, 1688, 1515, 1432, 1339, 1275, 1209, 1098, 1066, 1040, 1017, 874, 813, 763, 703, $609,520 \mathrm{~cm}^{-1}$; HR-ESI-MS: calcd for $\mathrm{C}_{9} \mathrm{H}_{15} \mathrm{~N}_{2} \mathrm{O}_{4} \mathrm{SNa}^{+} 289.0572$. Found 269.0570.

Bis(6-benzoyl-3-(2-methoxyphenyl)-sydnone imine-4-yl)-mercury(II) (30a). $\quad 0.15 \quad \mathrm{~g} \quad(0.50 \mathrm{mmol})$ of 6-benzoyl-3-(2methoxyphenyl)-sydnone imine are dissolved in $10 \mathrm{~mL}$ of THF (abs.) under an inert atmosphere. Then $0.60 \mathrm{~mL}(0.60 \mathrm{mmol})$ of LHMDS ( $1 \mathrm{M}$ in THF) are added at $\mathrm{rt}$. The mixture is cooled to $0{ }^{\circ} \mathrm{C}$ and treated with $0.08 \mathrm{~g}(0.30 \mathrm{mmol})$ of $\mathrm{HgCl}_{2}$. After stirring for $0.5 \mathrm{~h}$ at $0{ }^{\circ} \mathrm{C}$ the flask is warmed up to $\mathrm{rt}$ and stirred for another $3 \mathrm{~h}$. The crude product is purified by column chromatography (EE : PE : DCM $4: 2: 1)$. Yield: $0.18 \mathrm{~g}$ (93\%) of a white solid, mp $244{ }^{\circ} \mathrm{C}$ (decomp.). ${ }^{1} \mathrm{H}-\mathrm{NMR}\left(600 \mathrm{MHz}, \mathrm{CDCl}_{3}\right): \delta=$ 8.10-8.12 (m, 2H, 9/9'-H), 7.78-7.79 (m, 1H, 17-H), 7.44-7.46 (m, $2 \mathrm{H}, 11-\mathrm{H}+15-\mathrm{H}), 7.36-7.39\left(\mathrm{~m}, 2 \mathrm{H}, 10 / 10^{\prime}-\mathrm{H}\right), 6.99-7.03(\mathrm{~m}, 2 \mathrm{H}$, $16-\mathrm{H}+14-\mathrm{H}), 3.75(\mathrm{~s}, 3 \mathrm{H}, 19-\mathrm{H}) \mathrm{ppm} ;{ }^{13} \mathrm{C}-\mathrm{NMR}(150 \mathrm{MHz}$, $\mathrm{CDCl}_{3}$ ): $\delta=178.2$ (o, C-5), 172.7 (o, C-7), 152.8 (o, C-13), 143.4 (o, C-4), 138.1 (o, C-8), 133.5 (+, C-15), 131.0 (+, C-11), 129.3 (+, C-9/ 9'), $127.7\left(+, \mathrm{C}-10 / 10^{\prime}\right), 127.6$ (+, C-17), 125.2 (o, C-12), 121.1 (+, C16), 112.9 (+, C-14), 56.1 (+, C-19) ppm; IR (ATR): 3057, 3022, 2843, 1595, 1563, 1501, 1349, 1284, 1207, 1152, 1041, 1013, 935, 851, 753, 730, 709, $673 \mathrm{~cm}^{-1}$; HR-ESI-MS: calcd for $\mathrm{C}_{32} \mathrm{H}_{24} \mathrm{~N}_{4^{-}}$ $\mathrm{O}_{4} \mathrm{HgNa}^{+}$813.1361. Found 813.1344.

Bis(6-ethoxycarbonyl-3-morpholinyl-sydnone imine-4-yl)mercury(II) (30b). $0.12 \mathrm{~g}$ (0.50 mmol) of 6-ethoxycarbonyl-3morpholinyl-sydnone imine are dissolved in $10 \mathrm{~mL}$ of THF (abs.) under an inert atmosphere. Then $0.60 \mathrm{~mL}(0.60 \mathrm{mmol})$ of LHMDS ( $1 \mathrm{M}$ in THF) are added at $\mathrm{rt}$. The mixture is cooled to $0{ }^{\circ} \mathrm{C}$ treated with $0.08 \mathrm{~g}(0.30 \mathrm{mmol})$ of $\mathrm{HgCl}_{2}$. After stirring for $0.5 \mathrm{~h}$ at $0{ }^{\circ} \mathrm{C}$ the flask is warmed up to $\mathrm{rt}$ and stirred for another $3 \mathrm{~h}$. The crude product is purified by column chromatography (EE). Yield: $0.13 \mathrm{~g}$ (78\%) of a white solid, $\mathrm{mp} 243{ }^{\circ} \mathrm{C}$ (decomp.). ${ }^{1} \mathrm{H}-\mathrm{NMR}\left(600 \mathrm{MHz}, \mathrm{CDCl}_{3}\right): \delta=3.99\left(\mathrm{q}, J_{\mathrm{H}, \mathrm{H}}=7.1 \mathrm{~Hz}, 2 \mathrm{H}, 9-\mathrm{H}\right)$, 3.87-3.89 (m, 4H, 13/13'-H), 3.64-3.66 (m, 4H, 12/12'-H), $1.26(t$, $\left.J_{\mathrm{H}, \mathrm{H}}=7.1 \mathrm{~Hz}, 3 \mathrm{H}, 10-\mathrm{H}\right) \mathrm{ppm} ;{ }^{13} \mathrm{C}-\mathrm{NMR}\left(150 \mathrm{MHz}, \mathrm{CDCl}_{3}\right): \delta=$ 179.3 (o, C-5), 162.1 (o, C-7), 136.2 (o, C-4), 66.2 (-, C-13/13'), 61.2 (-, C-9), 56.5 (-, C-12/12'), 14.5 (+, C-10) ppm; IR (ATR): 2969, 2926, 2899, 2864, 1629, 1538, 1395, 1366, 1285, 1247, 1200, 1148, 1103, 1041, 970, 887, 786, $569 \mathrm{~cm}^{-1}$; HR-ESI-MS: calcd for $\mathrm{C}_{18} \mathrm{H}_{26} \mathrm{~N}_{8} \mathrm{O}_{8} \mathrm{HgNa}^{+}$707.1478. Found 707.1483.

(5-Benzamide-3-(2-methoxyphenyl)-1,2,3-oxadiazolium-4-yl) triphenylborate (31a). $0.10 \mathrm{~g}(0.34 \mathrm{mmol})$ of 6-benzoyl-3-(2methoxyphenyl)-sydnone imine are dissolved in $10 \mathrm{~mL}$ of THF (abs.) under an inert atmosphere. Then $0.41 \mathrm{~mL}(0.41 \mathrm{mmol})$ of LHMDS ( $1 \mathrm{M}$ in THF) are added at rt. The mixture is cooled to
$-10{ }^{\circ} \mathrm{C}$ and treated with $1.63 \mathrm{~mL}(0.41 \mathrm{mmol})$ of $\mathrm{BPh}_{3}(0.25 \mathrm{M}$ in THF). After stirring for $1 \mathrm{~h}$ at $-10^{\circ} \mathrm{C}$ the flask is warmed up to $\mathrm{rt}$ and stirred for another $3 \mathrm{~h}$. The crude product is purified by column chromatography (EE : PE $1: 5)$. Yield: $0.17 \mathrm{~g}(96 \%)$ of a white solid, mp $203{ }^{\circ} \mathrm{C}$ (decomp.). ${ }^{1} \mathrm{H}-\mathrm{NMR}$ (600 MHz, $\mathrm{CDCl}_{3}$ ): $\delta=8.56(\mathrm{~s}, 1 \mathrm{H}, 6-\mathrm{H}), 7.50-7.52(\mathrm{~m}, 1 \mathrm{H}, 11-\mathrm{H}), 7.29-7.32(\mathrm{~m}, 2 \mathrm{H}$, $\left.10 / 10^{\prime}-\mathrm{H}\right), 7.24-7.27$ (m, 1H, 15-H), 7.16-7.17 (m, 6H, 21/21'-H), 7.06-7.09 (m, 6H, 22/22'-H), 7.02-7.04 (m, 5H, 23-H + 9/9'-H), 6.99-7.00 (m, 1H, 17-H), 6.75-6.78 (m, 1H, 16-H), 6.49-6.50 (m, 1H, 14-H), 3.58 (s, 3H, 19-H) ppm; ${ }^{13} \mathrm{C}-\mathrm{NMR}$ (150 MHz, $\mathrm{CDCl}_{3}$ ): $\delta=166.0$ (o, C-5), 162.7 (o, C-7), 152.9 (o, C-13), 152.4 (br. s, o, C20), 142.4 (br. s, o, C-4), 135.3 (+, C-21/21'), 133.6 (+, C-11), 133.3 (+, C-15), 130.4 (o, C-8), 128.7 (+, C-10/10'), 127.8 (+, C-9/9'), 127.1 (+, C-17), 126.9 (+, C-22/22'), 124.5 (+, C-23), 122.5 (o, C12), $120.0(+, \mathrm{C}-16), 111.5(+, \mathrm{C}-14), 55.3(+, \mathrm{C}-19) \mathrm{ppm} ;{ }^{11} \mathrm{~B}-$ NMR (192 MHz, $\mathrm{CDCl}_{3}$ ): $\delta=-10.1$ (s) ppm; IR (ATR): 3288, 3062, 3040, 2995, 1711, 1569, 1500, 1430, 1382, 1286, 1254, 1201, 1052, 1021, 745, 700, 644, $569 \mathrm{~cm}^{-1}$; HR-ESI-MS: calcd for $\mathrm{C}_{34} \mathrm{H}_{28} \mathrm{~N}_{3} \mathrm{O}_{3} \mathrm{BNa}^{+}$560.2121. Found 560.2122.

(5-Ethylcarbamate-3-morpholinyl-1,2,3-oxadiazolium-4-yl) triphenylborate (31b). $0.10 \mathrm{~g}(0.41 \mathrm{mmol})$ of 6-ethoxycarbonyl-3morpholinyl-sydnone imine are dissolved in $10 \mathrm{~mL}$ of THF (abs.) under an inert atmosphere. Then $0.50 \mathrm{~mL}(0.50 \mathrm{mmol})$ of LHMDS ( $1 \mathrm{M}$ in THF) are added at $\mathrm{rt}$. The mixture is cooled to $-10{ }^{\circ} \mathrm{C}$ treated with $1.98 \mathrm{~mL}(0.50 \mathrm{mmol})$ of $\mathrm{BPh}_{3}(0.25 \mathrm{M}$ in THF). After stirring for $1 \mathrm{~h}$ at $-10{ }^{\circ} \mathrm{C}$ the flask is warmed up to $\mathrm{rt}$ and stirred for another $3 \mathrm{~h}$. The crude product is purified by column chromatography (EE : PE 1 : 2). Yield: $0.17 \mathrm{~g}(87 \%)$ of a white solid, mp $121{ }^{\circ} \mathrm{C}$ (decomp.). ${ }^{1} \mathrm{H}-\mathrm{NMR}\left(600 \mathrm{MHz}, \mathrm{CDCl}_{3}\right)$ : $\delta=7.33-7.35\left(\mathrm{~m}, 6 \mathrm{H}, 16 / 16^{\prime}-\mathrm{H}\right), 7.20-7.22\left(\mathrm{~m}, 6 \mathrm{H}, 17 / 17^{\prime}-\mathrm{H}\right)$, $7.11-7.13(\mathrm{~m}, 3 \mathrm{H}, 18-\mathrm{H}), 6.98(\mathrm{~s}, 1 \mathrm{H}, 6-\mathrm{H}), 4.12\left(\mathrm{q}, J_{\mathrm{H}, \mathrm{H}}=7.1 \mathrm{~Hz}\right.$, $2 \mathrm{H}, 9-\mathrm{H}$ ), 3.24 (br. s, $4 \mathrm{H}, 13 / 13^{\prime}-\mathrm{H}$ ), 3.00 (br. s, $4 \mathrm{H}, 12 / 12^{\prime}-\mathrm{H}$ ), $1.20\left(t, J_{\mathrm{H}, \mathrm{H}}=7.1 \mathrm{~Hz}, 3 \mathrm{H}, 10-\mathrm{H}\right) \mathrm{ppm} ;{ }^{13} \mathrm{C}-\mathrm{NMR}(150 \mathrm{MHz}$, $\mathrm{CDCl}_{3}$ ): $\delta=165.9$ (o, C-5), 152.7 (o, C-15), 149.7 (o, C-7), 136.7 (o, C-4), 135.1 (+, C-16/16'), $127.2\left(+, \mathrm{C}-17 / 17^{\prime}\right), 124.8$ (+, C-18), 65.7 $\left(-, \mathrm{C}-13 / 13^{\prime}\right), 63.4(-, \mathrm{C}-9), 56.1\left(-, \mathrm{C}-12 / 12^{\prime}\right), 13.9(+, \mathrm{C}-10) \mathrm{ppm}$; ${ }^{11} \mathrm{~B}-\mathrm{NMR}\left(192 \mathrm{MHz}, \mathrm{CDCl}_{3}\right): \delta=-10.2$ (s) ppm; IR (ATR): 3302, 3062, 2980, 2920, 2866, 1757, 1595, 1428, 1401, 1227, 1193, 1099, 1034, 892, 761, 733, 709, 651, 622, $550 \mathrm{~cm}^{-1}$; HR-ESI-MS: calcd for $\mathrm{C}_{27} \mathrm{H}_{29} \mathrm{~N}_{4} \mathrm{O}_{4} \mathrm{BNa}^{+}$507.2174. Found 507.2148.

\section{Conclusions}

In conclusion the anionic $\mathrm{N}$-heterocyclic carbenes derived from sydnone imines can be trapped by sulfur. These unstable sulfides can then be stabilized in situ upon methylation or by formation of transition metal complexes ( $\mathrm{Au}, \mathrm{Hg})$. Furthermore, deprotonated sydnone imines are suitable for covalent bond formation towards boron and for the formation of stable mercury(II) complexes in good yields. Structure determination was achieved by X-ray analysis.

\section{Conflicts of interest}

There are no conflicts to declare. 


\section{Acknowledgements}

Dr Gerald Dräger, University of Hannover (Germany) is gratefully acknowledged for measuring some HRMS spectra. The Deutsche Forschungsgemeinschaft (DFG) is gratefully acknowledged for the funding.

\section{References}

1 (a) A. Schmidt, S. Wiechmann and T. Freese, ARKIVOC, 2013, i, 424; (b) A. Nasr, A. Winkler and M. Tamm, Coord. Chem. Rev., 2016, 316, 68.

2 (a) C. A. Ramsden, Tetrahedron, 2013, 69, 4146; (b) C. A. Ramsden and W. P. Oziminski, Tetrahedron, 2014, 70, 7158; (c) W. P. Oziminski and C. A. Ramsden, Tetrahedron, 2015, 71, 7191.

3 W. D. Ollis, S. P. Stanforth and C. A. Ramsden, Tetrahedron, 1985, 41, 2239.

4 K. T. Potts, P. M. Murphy and W. R. Kuehnling, J. Org. Chem., 1988, 53, 2889.

5 A. Schmidt, S. Wiechmann and C. F. Otto, Adv. Heterocycl. Chem., 2016, 119, 143-172.

6 (a) M. Fèvre, J. Pinaud, A. Leteneur, Y. Gnanou, J. Vignolle, D. Taton, K. Miqueu and J.-M. Sotiropoulos, J. Am. Chem. Soc., 2012, 134, 6776; (b) X. Sauvage, A. Demonceau and L. Delaude, Adv. Synth. Catal., 2009, 351, 2031; (c) E. L. Kolychev, T. Bannenberg, M. Freytag, C. G. Daniliuc, P. G. Jones and M. Tamm, Chem.-Eur. J., 2012, 18, 16938; (d) X. Sauvage, G. Zaragoza, A. Demonceau and L. Delaude, Adv. Synth. Catal., 2010, 352, 1934; (e) J. Li, J. Peng, G. Zhang, Y. Bai, G. Lai and X. Li, New J. Chem., 2010, 34, 1330; (f) T. Le Gall, S. Baltatu and S. K. Collins, Synthesis, 2011, 3687; $(g)$ T. K. Olszewski and D. E. Jaskólska, Heteroat. Chem., 2012, 23, 605; (h) P. Bissinger, H. Braunschweig, T. Kupfer and K. Radacki, Organometallics, 2010, 29, 3987; (i) L. Tommasi and F. Sorrentino, Tetrahedron Lett., 2009, 50, 104.

7 (a) A. Schmidt, N. Münster and A. Dreger, Angew. Chem., 2010, 122, 2851; Angew. Chem. Int. Ed., 2010, 49, 2790; (b) A. Schmidt and A. Dreger, Curr. Org. Chem., 2011, 15, 2897; (c) A. Schmidt and T. Habeck, Lett. Org. Chem., 2005, 2, 37.

8 (a) Z. Guan, M. Gjikaj and A. Schmidt, Heterocycles, 2014, 10, 2356; (b) Z. Guan, S. Wiechmann, M. Drafz, E. Hübner and A. Schmidt, Org. Biomol. Chem., 2013, 11, 3558; (c) A. Schmidt, L. Merkel and W. Eisfeld, Eur. J. Org. Chem., 2005, 2124; (d) A. Dreger, R. Cisneros Camuña, N. Münster, T. A. Rokob, I. Pápai and A. Schmidt, Eur. J. Org. Chem., 2010, 4296.

9 (a) K. W. Ratts, R. K. Howe and W. G. Phillips, J. Am. Chem. Soc., 1969, 91, 6115; (b) H. Quast and E. Schmitt, Liebigs Ann. Chem., 1970, 732, 43; (c) A. R. Katritzky and H. M. Faid-Allah, Synthesis, 1983, 149.

10 A. Dreger, M. Nieger, M. Drafz and A. Schmidt, $Z$. Naturforsch., A: Phys. Sci., 2012, 67b, 359.
11 C. Färber, M. Leibold, C. Bruhn, M. Maurer and U. Siemeling, Chem. Commun., 2012, 48, 227.

12 C. A. Ramsden and W. P. Oziminski, Tetrahedron, 2015, 71, 6846.

13 J. Zhang, N. Pidlypnyi, M. Nieger, J. C. Namylo and A. Schmidt, Org. Biomol. Chem., 2014, 12, 2737.

14 (a) L. Benhamou, N. Vujkovic, V. César, H. Gornitzka, N. Lugan and G. Lavigne, Organometallics, 2010, 29, 2616; (b) L. Benhamou, V. César, H. Gornitzka, N. Lugan and G. Lavigne, Chem. Commun., 2009, 4720; (c) A. T. Biju, K. Hirano, R. Fröhlich and F. Glorius, Chem.-Asian J., 2009, 4, 1786.

15 S. Wiechmann, T. Freese, M. H. H. Drafz, E. G. Hübner, J. Namyslo, M. Nieger and A. Schmidt, Chem. Commun., 2014, 50, 11822.

16 T. Freese, A.-L. Lücke, C. A. S. Schmidt, M. Polamo, M. Nieger, J. C. Namyslo and A. Schmidt, Tetrahedron, 2017, 73, 5350.

17 I. A. Cherepanov, L. H. Kusaeva, I. A. Godovikov and V. N. Kalinin, Russ. Chem. Bull., 2009, 58, 2474.

18 (a) I. A. Cherepanov, N. V. Egorova, K. B. Nartinovich and V. N. Kalinin, Dokl. Akad. Nauk, 2000, 374, 64; (b) I. A. Cherepanov and V. N. Kalinin, Mendeleev Commun., 2000, 5, 181; (c) I. A. Cherepanov, A. S. Samarskaya, R. G. Nosov, I. A. Godovikov, Y. V. Nelyubina and V. N. Kalinin, Mendeleev Commun., 2014, 24, 386.

19 T. Freese, A.-L. Lücke, J. C. Namyslo, M. Nieger and A. Schmidt, Eur. J. Org. Chem., 2018, 1646.

20 V. N. Kalinin, S. N. Lebedev, I. A. Cherepanov, I. A. Godovikov, K. A. Lyssenko and E. Hey-Hawkins, Polyhedron, 2009, 28, 2411.

21 I. A. Cherepanov, S. N. Lebedev, A. S. Samarskaya, I. A. Godovikov, Y. V. Nelyubina and V. N. Kalinin, Mendeleev Commun., 2009, 19, 322.

22 A. S. Samarskaya, I. A. Cherepanov, I. A. Godovikov, A. O. Dmitrienko, S. K. Moiseev, V. N. N. Kalinin and E. Hey-Hawkins, Tetrahedron, 2018, 74, 2693.

23 S. N. Lebedev, I. A. Cherepanov and V. N. Kalinin, Russ. Chem. Bull., 2002, 51, 899.

24 K. Matsuda, Y. Imashiro and T. Kaneko, Chem. Pharm. Bull., 1970, 18, 128.

25 F. H. Allen, O. Kennard, D. G. Watson, L. Brammer, A. G. Orpen and R. Taylor, J. Chem. Soc., Perkin Trans. 2, 1987, 0, S1-S19.

26 G. M. Sheldrick, Acta Crystallogr., Sect. A: Found. Adv., 2015, A71, 3.

27 G. M. Sheldrick, Acta Crystallogr., Sect. A: Found. Adv., 2008, A64, 112.

28 (a) A. L. Spek, Acta Crystallogr., Sect. A: Found. Adv., 2009, D65, 148; (b) A. L. Spek, Acta Crystallogr., Sect. A: Found. Adv. , 2015, C71, 9. 